Teosofia: Indonesian Journal of Islamic Mysticism

Volume 6, Number 2, 2017: 77-86 DOI: 10.21580/tos.v6i2.3379

\title{
Response to Javanese Tradition in Kiai Shaleh Darat's Writings
}

\author{
Nur Ahmad \\ Vrije Universitait, Amsterdam \\ nur_ahmad@gmail.com
}

\begin{abstract}
The process of Islamization of Java is totally obscure. Because of the dark history of their conversion into Islam, and of misleading information from some orientalists, some members of Muslim communities mistaken some rituals as animistic and unIslamic. On the other extreme, ironically, theyconfuse creed that is in opposition to IslamwiththeIslamic orthodoxy. For the former, slametan is the perfect example, meanwhile, for the latter, sadjen becomes its representative. This paper aims to describe and analyzeKiai Șaleh Darat's response to both slametan and sadjen, some abangan customs (adat) - as Geertz would like to call - written down in Saleh's works. Based on this analysis, we also would provide a response to the error Geertz makes about the animistic attribute of slametan. In contrast to his imagination, slametanis perfectly Islamic and based on Islamic practice of communities from which Javanese Islam originate. In addition, Kiai Shaleh accepts the ritual and gives it Islamic justification. Meanwhile, sadjen - as Kiai Shaleh points out - is totally an opposition to the most fundamental credo of Islam, namely the Unity of God, "Tauhid."
\end{abstract}

Keywords: islamization of Java; abangan; slametan; sadjen

\section{A. Introduction}

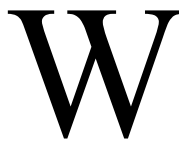

hen Islam as "the unconditional surrender to the will of God" was preached to the Arabic people of the $7^{\text {th }}$ century, it faced for the first time, system of customsto which three different responses were given. First, Islam totally banned some of them. Second, it confirmed some of them with more or less alteration so they were in accordwiththe fundamental teaching of Islam. Finally, it confirmed and strengthened some of them without any alteration. Every response has its own

\footnotetext{
${ }^{1}$ Vincent J. H. Houben. "Southeast Asia and Islam." The Annals of the American Academy of Political and Social Science 588 (2003): 149-70. http://www.jstor.org/stable/1049859.
} 
underlying reasons to determine which practice should be totally rejected and which should be assimilated. In the history of Islamization, ${ }^{2}$ theseresponses and their underlying reasons become the golden rule for Islam when it enters every new civilization. Based on these foundations, Kiai Shaleh Darat ${ }^{3}$ responses to the local beliefs of Javanese people. The result, he determined that some of the rituals, which are exclusively attributed to abangan by Geert $z^{4}$ and therefore are not Islamic, are perfectly acceptable to Islam.

\section{B. The Prophet and Pre-Islamic Creed and Rituals}

When Qurais tribewas desperate to stop Muhammad from his teaching, they tried to negotiate with the prophet tomix the two system of beliefs, namely paganism and Islam. The prophet and his Muslims followers, the idol worshippers offer, should practice pagan tradition in a year, they in exchange would prostate before God of Islam in the other year. The Prophet, as God commands him in Quran chapter The Disbelievers (109), strongly denounces this offer. ${ }^{5}$ Instead He purifies Islam the governing doctrine of Islam, namely the Unity of God. This response becomes an orthodoxy form in Islam for any encounter with every system of creed. In other words, Islam purifies God from partnerthat the pre-Islamic Arabian community commonly had in their mind in those eras. Even though that, the word for God in the community is not abrogated but it is purified. For that reason, the early revelation of the Quran (Mecca revelation) always address "God" Allâh as "the Lord" rabb. Only then after the non-believer asked about what actually Muhammad - peace be upon him - meant by "Lord", Allâh was introduced with purifying the name from any partner ascription.

${ }^{2}$ Mark R. Woodward and Association for Asian Studies., Islam in Java: Normative Piety and Mysticism in the Sultanate of Yogyakarta, The Association for Asian Studies Monograph; No. 45; Monographs of the Association for Asian Studies, 45. (Tucson, Ariz.: The University of Arizona Press, 1989), 53.

${ }^{3} \mathrm{He}$, Muhammad Shaleh bin 'Umar Darat as-Samarani, is one of Indonesian greatest Islamic scholars in the 19th century. Born in Jepara, he travelled across the Java, Madura, and finally to Mecca in order to gain Islamic knowledge from Muslim scholars in his era. He writes all of his treatises in Java language but in Arabic transcript, known as pegon. In Semarang he trained many students who later become notable Muslim scholars including the first and the only Grand Imam of Nahdatul 'Ulama, Hashim Asy'ari, and the founder of Muhammdiyah, Ahmad Dahlan. Nur Ahmad, "Kualitas Hadis-Hadis dalam Kitab Syarah al-Hikam Karya Kiai Shaleh Darat" (undergraduate, UIN Walisongo, 2014), 55-74, http://eprints.walisongo.ac.id/3932/.

${ }^{4}$ In chapter one to nine of his The Religion of Java, Geertzlists several rituals and beliefs of Javanese people which he attributed to abangan people. This attribution as we would like to prove in this paper is not valid. Clifford. Geertz, The Religion of Java, Phoenix ed. (Chicago: University of Chicago Press, 1976).

${ }^{5}$ Abū al-Ḥasan 'Alī ibn Aḥmad Wāhịid̄, Reasons and Occasions of Revelation of the Holy Quran = Asbāb Nuzūl al-Qur'ān (Beyrouth, Liban: Dar al-Kutub al-Ilmiyah, 1991), 496. 
Response to Javanese Tradition ....

In the realm of rites, the more flexible and fluid response Islam gave to the first community it faced. The pilgrimage to the Ka'ba which has already existed for long time before is kept and purified from unethical practices such as circumambulating Ka'ba with stark naked. Islam also strengthen the notion of ethical concepts held by Arabian people. They, for example, greatly respect older people. They also value person as very honorable when they connect brotherhood between people.

Based on these concepts Muslim scholars promote the notion of fluid integration between local tradition or custom and Islam. The fact that how diverse cultures into which Islam enters and builds one Islamic civilization, since we cannot have a civilization without a religion, shows what we mean here. Indonesia, Persian, Moroccan cultures are difference from each other, but there are all bounded in one Islamic civilization.

In Indonesia, the context we would address in this paper, a unique "integration" between local customs and Islam happens in some degree. Even though Geertz believes that the rituals practiced by Javanese people are originated from the Javanese religious system, ${ }^{6}$ Hefner points out to the overlooking of the Islamic influencein the tradition by his and others Dutch Orientalists. ${ }^{7}$ For the later, there is a growing influence of Islamic teaching in the local customs. ${ }^{8}$

\section{Customs of Javanese people and Kiai Shaleh's response}

\section{Slametan: Its Islamic Root}

Geertz exaggerates when he charaterizesslametanas the communal feast wherein "Friends, neighbors, fellow workers, relatives, local spirits, dead ancestors, and nearforgotten gods all get bound... ${ }^{9} \mathrm{He}$ explicitly describes it as a core animistic rite performed byJavanese people. In contrast, in a brilliant way, a contemporary Indonesianist, Mark Woodward, provides a more appropriate interpretation of slametan. He disputes Geertz's presumption of animistic and therefore not Islamic rite of slametan and characterizesis as"a ritual meal at which Arabic prayers are recited and food is offered to the Prophet Muhammad, saints, and ancestors, who are implored to shower

${ }^{6}$ Geertz, The Religion of Java, 1.

${ }^{7}$ Robert W. Hefner, "Islam in an Era of Nation-states: Politics and Religious Renewal in Muslim Southeast Asia”, in Robert W. Hefner \& Patricia Horvatic (eds.), Islam in an Era of Nationstates: Politics and Religious Renewal in Muslim Southeast Asia (Honolulu: University of Hawaii Press, 1997), 11.

${ }^{8}$ Hefner., 12.

${ }^{9}$ Geertz, The Religion of Java, 11. 
blessings on the community." 10 This meal feast is an expression of Islamic Tradition in Javanese society. For Javanese Muslims, the idea of performing the rite is that they could derive blessing, barākah, when they show their gratitude,syukr,such as when someoneis getting a baby, having a new house, marrying someone, or in every occasions they consider as "favor."

This tradition is based on many hadith in which the prophet has been reported to give blessing to small part of meal by his prayer so it could be eaten by many of his companions. One hadith reports,

"On the day of the battleof Tabük, the people becamehungry and said: '0 Messenger of Allah, why don't you give uspermission to slaughter ourcamels, and we will eat them andmake use of their fat.' TheMessenger of Allah said: 'Dothat.' Then 'Umar came and said:'0 Messenger of Allah, if you dothat we will have few mounts. Rather call them to bringwhatever provisions they haveleft, then pray to Allah overthem, asking Him to bless themfor them, and perhaps Allah will bless them.' The Messenger ofAllah ji said: 'Yes.' He calledfor a leather mat and spread itout, then he called for their leftover provisions. One manbrought a handful of corn, another brought a handful ofdates, and another brought apiece of bread, until a little foodhad been collected on the leathermat. Then the Messenger ofAllah 0, prayed for blessing forit, then he said: 'Put it in yourvessels.' They filled their vesselsuntil there was no vessel left inthe camp that was not filled. They ate until they were full, andthere was plenty left over. Thenthe Messenger of Allah said:'I bear witness that none has theright to be worshipped but Allahand that I am the Messenger ofAllah. No one who meets Allah(believing) in them and notdoubting them will be kept awayfrom Paradise."11

Beside this hadith, there are so many hadiths reporting the blessing the Prophet had on meals. In most of them, the situations were always that the companions were lack of meals or near to starvation. The Prophet prays on the meals for the companions and they eat together after that. This practice of the prophet becomes the theological basis for Muslims in many cultures to have communal feast wherein people eat together.

In Java, a uniqueform of this practice has existed since the first wave of Islamization. Javanese people perform a communal meal-feast for specific reasons such as birth, wedding, and death; with specific food offerings such as apem, rice-flour pancakes, and specific recitation of the Quran. Since the people of Java has become to understand religion more rigid, this tradition encounters a challenge from so call "pure

\footnotetext{
${ }^{10}$ Mark R. Woodward, Java, Indonesia and Islam, Muslims in Global Societies Series; v. 3; Muslims in Global Societies Series ; v. 3. (Dordrecht; Springer, 2011), 113.

${ }^{11}$ Muslim ibn al-Hajjāj al-Qushayrī et al., English Translation of Sahîh Muslim, ed. Abū Ṭāhir Zubayr 'Alī Za'ī, vol. 1, (Riyadh: Darussalam, 2007), 124-25.
} 
Response to Javanese Tradition ....

Islamic teaching." In his writings, Kiai Shaleh discusses the tradition practiced by Javanese people in his era; he pays a great attention to the common people who questions a theological status of these practices so those who are practicing it become at peace because their tradition is in accordance with Islam.

In regard to slametan for death people, Kiai Shaleh answers that slametan for death people is kind ofcharity (sadaqah). Before the people eat the food, they recite the holy Quran and pray for the newly death and their death ancestors in order to copy the practice of the Prophet. Therefore, according to Kiai Shaleh Darat, this aims giving is encouraged by Islam. ${ }^{12} \mathrm{He}$ basis this fatwa on hadith which reports that a main said,

"It wasnarrated from 'Aishah that a mancame to the Prophet and said:" Messenger of Allah, mymother died suddenly and didnot leave a will. I think that if shehad been able to speak, shewould have given charity. Willshe have any reward if I givecharity on her behalf?" He said:"Yes."13

However, he also makes a correction of the practice. His legal opinions limit the practice with three conditions. First, the almsgiving is prohibitedwhen the person who died owe debts to God and/or to man such as alms (zakāt). ${ }^{14}$ Second, it also prohibited when the person who died leaves children who are not mature (bālig), before the children receive their inheritance. ${ }^{15}$ Third, the almsgiving is not limited to the third, the seventh, or the thousand daysafter the person died as Javanese usually do. ${ }^{16}$

These first two constrainsdeliver the people of Java to creatively compromise the tradition with the criteria of Islam. Therefore, instead of funding the feast using the inheritance of the death, neighborhoods voluntarily raise funds when they come to show their empathy to the newly bereaved family. From this sum of money, the family finance the ceremony without breaking the law of Islam (shari'a).

The other mode of collecting money is by the neighborhood-based system namely uang kematian, money for the death. The basic community association, Rukun Tetangga (RT), which usually comprises of 15-30 households are asked to give some money arranged by the secretary of the RT. In many towns the amount money derived from one household is 5,000 to 10,000 rupiahs. Some rich people would give more than the agreed amount. This innovative scheme also applies to the next higher administrative level,

\footnotetext{
${ }^{12}$ Saleh b. 'Umar Darat. Samarani, Majmū 'at Al-Shañ̄'ah Al-Käfiyah Lil-'Awwām (Cirebon: Maktabah al-Mișriyyah, n.d.), 88-89.

${ }^{13}$ al-Qushayrī et al., Sahîh Muslim, 3:50-51.

${ }^{14}$ Samarani, Majmū 'at al-Shañ 'ah al-Kä fiyah Lil-'Awwām, 88.

${ }^{15}$ Samarani, 89.

16 Samarani.
}

Teosofia: Indonesian Journal of Islamic Mysticism, Volume 6, Number 2, 2017 
Rukun Warga usually comprises of several Rukun Tetangga. In some cases, if the death person has children are still in elementary school, junior high school or even senior high school, their friends set up fund to help their friend. Thus, in many cases the sum of money could meet the need of funeral process, such as to hire gravedigger, held slametan with good food et cetera.

Contrary to what Kiai Shaleh teaches, ${ }^{17}$ the third has become the living practice within Javanese Muslims. Most Javanese people always pray for the death starting from the first day to the seventh, then the fortieth, hundredth, and one thousandth after the death. Javanese people, even though they are poor, would strive to organize the ceremony for their death ancestors which rise to theological problem we would discuss soon. While for the nominal Muslims, the cycle ends with the one thousandth (Javanese, nyewu), for santri community the cycle would continue to the annual commemoration. When the death person is believed by many people as great Kiai, sometimes referred as "wäli", the ceremony would be attended by tens of to hundreds of thousands of people. For example, Kiai Shaleh's death commemorationhimself, being revered by many Muslims, common people and elite, as great Kiai of Java, is attended by thousand peoples every Syawwā 110 .

Muslim fundamentalists, usually those who held Wahabism or are related to it,and some orientalists blindly judgethe ritual asBuddhist-Hindu origin orat least ignore itsIslamicbases. ${ }^{18}$ Our prime example is the series of book written by an 8 -year student of a university at the Kingdom of Saudi Arabian. ${ }^{19}$ Mahrus Ali, who decisively claim as ex-NU scholar, writes series of controversial books condemning the rituals practiced by Muslims nominals in Indonesia, including Tahlilan a contemporary term of slametan for deaths. ${ }^{20}$ In order to clarify his claim and belief,a representative of NU came to his house in 2010, when the books sparked off public debate. ${ }^{21}$ The result proves his false claim. He was not an NU scholar, nor he shows a complete understanding of the matters he addresses in his books.

\footnotetext{
17 Samarani, 89.

${ }^{18}$ Mary Chamberlain, Caribbean Migration: Globalized Identities (Routledge, 2002), 116.

19“Membongkar Kebohongan H Mahrus Ali dan Rekayasa Busuk Wahabi - Kompasiana.com," Kompasiana, accessed November 13, 2016,

http://www.kompasiana.com/luqmanfirmansyah/membongkar-kebohongan-h-mahrus-ali-danrekayasa-busuk-wahabi_550054d3a333111e73510971.

${ }^{20} \mathrm{His}$ books are H. Mahrus Ali, Mantan kiai NU menggugat tahlilan, istighosahan dan ziarah para wali (Solo: Laa Tasyuki Press, 2007) and Mantan Kiai NU meluruskan ritual-ritual kiai ahli bid'ah yang dianggap sunnah: nisfu sya'ban, rebo wekasan, tingkepan \& bid'ah-bid'ah dari Muharram-Dzulhijjah (Laa Tasyuki Press, 2008).

${ }^{21}$ Such as what has done by Geertz, The Religion of Java, 72.
} 
Response to Javanese Tradition ....

In contrast to the misleading ideas, slametan actually originates from the huge body of Islamic civilization. There are two valid arguments justify our point of view. First, from historicalobservation, Woodward convincingly points towards the Islamic root of slametan. $^{22}$ He tracesthe origin of slametanto the practice of nercha by Muslim communities in Kerala, South India. ${ }^{23}$ His major argument is the striking resemblance of the type of food offered in both events, namely apem, rice-flour pancakes. In addition, two communities also hold very firm belief that saints, to which slametan is dedicated, would pour blessings over the food. This is not to point another same core rituals and school of Islamic jurisprudence, namely Shafi'ite, held by two communities

Second, from linguistic point of view, Woodward highlights that the word kendhuri, which is the other popular name of slametan, is derived from the Persian termkundur, tablecloth. ${ }^{24}$ This term isemployed by Shafiitejurisprudence books for "feasts heldin honor of the Prophet Muhammad,saints, and souls of the dead." ${ }^{25}$ For Javanese people, nowadays the central idea of kendhuri is thanksgiving for any favor they received from God.The Quran says, "And as for the blessing of thy Lord, proclaim!". This proclamation of the blessing embedded in any favorable things someone receives is the basis of confirming kendhuri from the Islamic point of view.

\section{Sadjen: the remainder of the old Javanese religion}

Another Javanese ritual that Kiai Shaleh Darat addresses in his writings is sadjen. The term means a mixed feature of food and burned incense placed in small bucket "for the well-being for of the deceased." ${ }^{26}$ In other word, as Geertz describes, sadjen is "a special offering for the spirits ..."27 For example, peasants would place sadjen in their field because of the belief that spirits, danyang, have an absolute control of the field. They try to maintain the good relationship with, or to show their respect to danyang so the spirits do not interfere with their business.

Shaleh's answer to this belief is a firm and unshakable one. He categorize the act of giving sadjen with underlying reason to show respect and to belief the great power of

${ }^{22}$ Woodward and Association for Asian Studies., Islam in Java, 53-60.

${ }^{23}$ Woodward., 57.

${ }^{24}$ Woodward, Java, Indonesia and Islam, 116. See also Howard M. Federspiel, Islam and Ideology in the Emerging Indonesian State: The Persatuan Islam (Persis), 1923 to 1957(BRILL, 2001), 335.

${ }^{25}$ Woodward, Java, Indonesia and Islam, 116. See also Federspiel, Islam and Ideology in the Emerging Indonesian State, 335.

${ }^{26}$ Chamberlain, Caribbean Migration, 115.

${ }^{27}$ Geertz, The Religion of Java, 41. 
danyang into apostasy. ${ }^{28}$ Salim shows that the reason for this judgement is because it breaks the governing maxim of Islam, namely "Tauhi $d^{. "}{ }^{29}$ To believe in One God means that only Him could actually give benefit and avoid harm on human. To violates this doctrine means an apostasy (murtad). Kiai Shaleh sets three aspects from which someone is defined as an apostate. ${ }^{30}$ First, based on their convictions, that is when someone rejects the obligatory of firm religious obligations, such as five canonical prayers. ${ }^{31}$ Second, based on their sayings, for example when someone says that "God is three." ${ }^{32}$ Third, based on their outward behavior or clothes, for example when someone gives sadjen to "spirits." ${ }^{33}$ Shaleh values that sadjen violates "Tauhì d", because someone believes that danyang"could give benefit and avoid harm on us. The act of sadjen is analogically the same with worshipping idols.

Shaleh's belief is deeply rooted in the Islamic teaching. His basis is what the Prophet of Islam teaches when he faces paganism of the Arab. In the section The prophet and pre-Islamic creed and rituals, we have pointed out to the Islamic response towards the idea of mixing beliefs between paganism and Islam. This is the golden rule on the relation between Islam and local belief and if we would like to distinguish between santri and abangan, as Geertz uses them, the only things that differentiates the two is their responds to this idea. The former rejects the idea of ascribing supernat ural power to danyang, whereas, the former confirms the notion and shows their beliefs in giving sadjen.

\section{Conclusion}

There are some conclusions we would like to highlight here. First, when Islam enters into a new civilization, it provides two expressions. In the one hand, an infinite flexibilityis the key factor for it builds on old civilization and gives new meaning and strength to the symbolical language of the rituals. On the other, Islam strictly denounces any doctrine and creed that are exactly the opposite to its foundation, that is the Unity of God (Tauhi d). Second, in specific case in Javanese Muslim, Kiai Shaleh values that slametan is the exact example for the former. In contrast to what some western scholars,

${ }^{28}$ Samarani, Majmū 'at al-Shan̄' 'ah al-Kā fiyah lil-'Awwām, 23-24.

${ }^{29}$ Abdul Salim, "Majmu'at Al-Shari'ah Al-Kafiyah Li Al-’Awam Karya Kiyai Saleh Darat” (Ph.D Thesis, UIN Jakarta, 1994), 191.

${ }^{30}$ Samarani, Majmū 'at Al-Shan̄' ah Al-Käfiyah Lil-'Awwām, 23-24.

${ }^{31}$ Ibnu Fikri, Konstruksi Nasionalisme Perspektif Ulama Jawa Tengah Abad XIX (Analisis Filologis terhadap Karya-Karya Kyai Sholeh Darat Semarang) (Semarang: Lembaga Penelitian dan Pengabdian Kepada Masyarakat IAIN Walisongo, 2013), 75.

${ }^{32}$ Salim, “Majmu'at al-Shari' ah Al-Kafiyah li al-'Awam Karya Kiyai Saleh Darat,” 191.

${ }^{33}$ Salim. 
Response to Javanese Tradition ....

such as Geertz, and Muslim fundamentalist, Shaleh confirms the Islamic basis of slametan. We also point to thedeep-rooted practiceof itin Muslim communities of South and Indian and/or of Persian from which Javanese Islam originates. On the other antipode, sadjen is the representative example which sets the limit of toleration in Islamic orthodoxy. In his writings, Kiai Shaleh ensure that the action of believing in the great power of danyang is an apostasy. He purifies the Islamic doctrine of tauhi $\bar{d}$ from any deviation that entirely destroys its foundation.

\section{Bibliography}

Ahmad, Nur. "Kualitas Hadis-hadis dalam Kitab Syarah Al-Hikam Karya Kiai Shaleh Darat." Undergraduate, UIN Walisongo, 2014. http://eprints.walisongo.ac.id/ $3932 /$.

Ali, Mahrus. Mantan Kiai NU meluruskan ritual-ritual kiai ahli bid'ah yang dianggap sunnah: nisfu sya'ban, rebo wekasan, tingkepan \& bid'ah-bid'ah dari Muharram-Dzulhijjah. Laa Tasyuki Press, 2008.

Ali, Mahrus. and Abu Yahya Arif. Mustaqim. Mantan kiai NU menggugat tahlilan, istighosahan dan ziarah para wali: muktamar NU ke-1 di Surabaya tanggal 13 Rabi'us Tsani 1345 H/21 Oktober 1926 M menyatakan bahwa selamatan setelah kematian adalah bid'ah yang hina! [Solo]: Laa Tasyuki Press, 2007.

Chamberlain, Mary. Caribbean Migration: Globalized Identities. Routledge, 2002.

Federspiel, Howard M. Islam and Ideology in the Emerging Indonesian State: The Persatuan Islam (Persis), 1923 to 1957. BRILL, 2001.

Fikri, Ibnu. Konstruksi Nasionalisme Perspektif Ulama Jawa Tengah Abad XIX (Analisis Filologis Terhadap Karya-Karya Kyai Sholeh Darat Semarang). Semarang: Lembaga Penelitian dan Pengabdian Kepada Masyarakat IAIN Walisongo, 2013.

Geertz, Clifford. The Religion of Java. Phoenix ed. Chicago: University of Chicago Press, 1976.

"Membongkar Kebohongan H Mahrus Ali Dan Rekayasa Busuk Wahabi Kompasiana.com." Kompasiana. Accessed November 13, 2016. http://www.kompasiana.com/luqmanfirmansyah/membongkar-kebohongan-hmahrus-ali-dan-rekayasa-busuk-wahabi_550054d3a333111e73510971.

Qushayrī, Muslim ibn al-Ḥajjāj al-, Nāsiruddīn Khattāb, Khattāb Hudā, and Abū Khalīl. English Translation of Sahīh Muslim. Edited by Abū Țāhir Zubayr 'Alī Za'̄̄. Vol. 1. Riyadh: Darussalam, 2007.

Qushayrī, Muslim ibn al-Hajjāj al-. English Translation of Sahīh Muslim. Edited by Abū Țāhir Zubayr 'Alī Za'̄̄. Vol. 3. Riyadh: Darussalam, 2007. 
Salim, Abdul. "Majmu'at al-Shari'ah al-Kafiyah li al-'Awam Karya Kiyai Saleh Darat." Ph.D Thesis, UIN Jakarta, 1994.

Samarani, Saleh b. 'Umar Darat. Majmū'at Al-Sharī'ah Al-Kāfiyah Lil-'Awwām. Cirebon: Maktabah al-Mișriyyah, n.d.

Wāḥid̄̄, Abū al-Ḥasan 'Alī ibn Aḥmad. Reasons and Occasions of Revelation of the Holy Quran = Asbāb Nuzūl Al-Qur'ān. Beyrouth, Liban: Dar al-Kutub al'Ilmiyah, 1991.

Woodward, Mark R. Java, Indonesia and Islam. 1 online resource (xiii, 275 pages). vols. Muslims in Global Societies Series; v. 3; Muslims in Global Societies Series; v. 3. Dordrecht; Springer, 2011. EBSCO host. http://search.ebscohost.com/ login.. spx ?direct $=$ true $\&$ scope $=$ site $\& d b=$ nlebk $\& d b=$ nlabk $\& A N=371723$.

Woodward, Mark R. and Association for Asian Studies. Islam in Java: Normative Piety and Mysticism in the Sultanate of Yogyakarta; Monographs of the Association for Asian Studies; 45. Tucson, Ariz.: The University of Arizona Press, 1989. 